\title{
NATIONAL ACCOUNTS DATA AND MACROECONOMIC ANALYSIS: A COMPARATIVE STUDY OF THE CZECH REPUBLIC, GERMANY, GREECE, IRELAND AND SLOVENIA
}

\author{
Maks Tajnikar, Nina Ponikvar *
}

\begin{abstract}
:
In this paper there are analysed the characteristics of various important macroeconomic variables in the Slovenian economy and compared with the macroeconomic development in the Czech Republic, Germany, Greece and Ireland in two periods of 1997-1999 and 2000-2002. The main objectives of the paper are to observe changes in the macroeconomic variables of the analysed countries during the observed periods, to determine the sources of any differences in macroeconomic characteristics between Slovenia and the other analysed countries and, finally, to suggest some steps and measures to improve the macroeconomic situation of these countries. Data from national accounts are used in the analysis. In terms of methodology, the paper is based on post-Keynesian economic theory and its long-term economic model of a market economy with private ownership. Based on the analysis it was concluded that in all analysed countries there should be a greater emphasis on tax policy to create an incentive for investing and saving, on incomes policy to control the dynamics of nominal wages, and on technological policy as a prerequisite for improved economic efficiency.
\end{abstract}

Keywords: long-run macroeconomic model, national accounts, post-Keynesian economic theory, Slovenia, Czech Republic, Germany, Greece, Ireland

JEL Classification: B 500, E 120

\section{Introduction}

In this paper there are analysed the characteristics of the most important macroeconomic variables in the Slovenian economy in two separate periods and compared against macroeconomic situations found in the Czech Republic, Germany, Greece and Ireland. The focus is firstly to observe changes in the macroeconomic development of the analysed countries during the research periods, secondly to determine the sources of any differences in macroeconomic characteristics between Slovenia

*) University of Ljubljana, 17, Kardeljeva Sq., SI - 1000 Ljubljana (e-mail: maks.tajnikar@ef.unilj.si,nina.ponikvar@ef.uni-lj.si). 
and other observed countries and, thirdly, to suggest measures to improve their macroeconomic situations. The authors therefore try to identify those macroeconomic variables that are crucial from the economic policy point of view. Data from national accounts are used as the starting point of the analysis. When properly combined with a suitable economic model, the data allow us to closely examine national macroeconomic conditions and to forecast macroeconomic dynamics.

In methodological terms, the paper is based on post-Keynesian economic theory and its long-term economic model of a market economy with private ownership (Robinson and Eatwell, 1973; Robinson, 1962; Tajnikar, 1996, 2000). In this model's long-term analysis, the key economic aggregates are investment and the investment rate, the growth of labour and production capacities, the technical progress, the nominal and real wages, the price level and the propensity to save. In the short run, aggregate data on consumption, capacity utilisation, production costs and other elements of effective demand are also important. Through this analysis, long-term economic changes crucial to the macroeconomic situation can be explained and understood on the basis of short-term data.

\section{Data}

The starting point of the analysis involves data drawn from the tables "Relations among Product, Income, Savings and Net Lending Aggregates" and "Cost Components of the Gross Domestic Product" taken from the United Nations' National Accounts Statistics (2003, 2005). Fundamental aggregates in the analysis are gross domestic product (GDP) and gross national disposable income (GDY). Together with the current account balance $(\mathrm{X})$, the latter gives domestic aggregate consumption (Y). Domestic savings are defined as the difference between real gross national disposable income and final consumption expenditure (Yd). On the other hand, total savings ( $\mathrm{S}$ ) also include the current account balance. By profits in the economy $(\mathrm{Pr})$ there are understood the gross operating surplus, which is the sum of the consumption of fixed capital and the net operating surplus. The difference between GDP and profits, defined as above, represents household and state incomes. In the model, the latter are called wages - real wages (Wr) and nominal wages (Wn). In the macroeconomic model applied in the analysis, the number of people employed (L) and the value of capital (K) in national economies are also used.

Capital is a category that is formed from gross investment (I). The value of assets in national economies $(\mathrm{K})$ would therefore be a suitable variable to use in the model. Even theoretically, capital is not a factor of production that is easy to define (Arestis, 1992, p. 65; Garegnani, 1970) and it becomes even more difficult to measure and assess it in practice. Since Slovenian statistics do not include data on assets and the international statistics also do not include them, even if data on assets were available for some countries, the value of assets (capital) had to be estimated otherwise. The value of assets for the analysed countries was calculated from the consumption of fixed capital by assuming and applying a uniform depreciation rate for all countries. The depreciation rate applied of $4.18792 \%$ was calculated from Slovenian survey data from 1999 (Statistical Office of the Republic of Slovenia, 2001). Therefore, the estimated capital value in national economies is based on the presumption that the depreciation rate was the same for all the countries and for all 
of the analysed years. Calculating asset value on the basis of fixed capital consumption might be theoretically unacceptable to some and the assumption of a uniform depreciation rate too daring by others. However, no alternative solution could be found to estimate the value of capital $(\mathrm{K})$ according to the available statistical data and the results obtained by applying the post-Keynesian model could be different if some other capital measurement was applied.

The whole period is split into two three-year periods (1997-1999 and 20002002). For each period the average values of the aggregates are calculated. However, the availability of such data in international statistics varies among countries with data being more extensive for certain countries and less for others. Further, national accounts data are usually published with relatively long time lags and the analysed data and research periods selected are mainly based on the availability of such data. The selection of the analysed countries is therefore twofold. Firstly, countries were selected on the basis of data availability. Among these countries were selected a few, for which a comparison with Slovenia could reveal some interesting features. The analysed countries chosen are all members of the European Union. Three of them are old members: Germany as one of the most developed, Greece as one of the least developed countries and Ireland as a country that experienced one of the highest growth rates among members of the European Union during the investigated period. The Czech Republic and Slovenia were chosen among new members, although both of the countries were still associate members of the EU during

Table 1

National Accounts Data of Analysed Countries in 1997-1999 and 2000-2002

\begin{tabular}{|c|c|c|c|c|c|c|c|c|c|c|}
\hline \multirow{2}{*}{$\begin{array}{l}\text { Million } \\
1995 \text { US \$ }\end{array}$} & \multicolumn{2}{|c|}{ Slovenia } & \multicolumn{2}{|c|}{ Czech Republic } & \multicolumn{2}{|c|}{ Germany } & \multicolumn{2}{|c|}{ Greece } & \multicolumn{2}{|c|}{ Ireland } \\
\hline & 1997-99 & 2000-02 & 1997-99 & 2000-02 & 1997-99 & 2000-02 & 1997-99 & 2000-02 & 1997-99 & $2000-02$ \\
\hline GDP & 22,682 & 25,429 & 58,404 & 63,061 & $2,566,938$ & $2,631,171$ & 128,929 & 147,875 & 87,162 & 115,711 \\
\hline X & -286 & -93 & $-2,105$ & $-3,492$ & $-9,743$ & 21,264 & $-9,711$ & $-8,031$ & 1,154 & -767 \\
\hline $\mathrm{Yd}$ & 17,438 & 19,364 & 43,142 & 46,648 & $1,972,583$ & $2,053,385$ & 110,475 & 123,539 & 56,111 & 70,555 \\
\hline Sd & 5,447 & 6,186 & 14,639 & 14,528 & 551,655 & 541,807 & 18,453 & 26,778 & 21,307 & 26,266 \\
\hline$S$ & 5,733 & 6,279 & 16,774 & 18,020 & 561,398 & 520,543 & 28,164 & 34,809 & 20,153 & 27,033 \\
\hline I & 5,733 & 6,279 & 16,774 & 18,020 & 561,398 & 520,543 & 28,164 & 34,809 & 20,153 & 27,033 \\
\hline $\operatorname{Pr}$ & 5,253 & 6,006 & 28,716 & 31,069 & $1,020,013$ & $1,009,257$ & 66,155 & 84,298 & 41,387 & 54,877 \\
\hline $\mathrm{Wr}$ & 17,429 & 19,423 & 29,688 & 31,992 & $1,546,925$ & $1,621,914$ & 62,774 & 63,577 & 45,775 & 60,834 \\
\hline $\mathrm{Wn}^{*}$ & 22,569 & 39,779 & 36,297 & 43,007 & $1,591,317$ & $1,746,296$ & 74,950 & 83,035 & 51,564 & 76,766 \\
\hline K & 85,306 & 92,296 & 274,188 & 305,712 & $9,051,957$ & $9,414,634$ & 276,699 & 313,542 & 208,136 & 282,881 \\
\hline $\mathrm{L} * *$ & 879 & 896 & 5,021 & 4,852 & 37,632 & 38,777 & 3,888 & 3,927 & 1,516 & 1,734 \\
\hline
\end{tabular}

* Nominal wages are in current prices.

** Number of persons employed in thousand.

Source: National Accounts Statistics, UN, 2003 and 2005. 
the research period. In Table 1 there are the averages of the aggregates from national accounts data for each investigated period for Slovenia, the Czech Republic, Germany, Greece and Ireland for the periods 1997-1999 and 2000-2002. All aggregates are in fixed US dollar prices from 1995.

For the purpose of the analysis ratios between various macroeconomic variables are calculated and presented. The ratios are rounded-up in order to be more convenient for a graphic presentation, review and interpretation. Data from Table 1 were used to calculate the ratios shown in Table 2.

Table 2

Ratios of the Analysed Countries' Fundamental Economic Aggregates in 1997-1999 and 2000-2002

\begin{tabular}{|c|c|c|c|c|c|c|c|c|c|}
\hline & \multicolumn{5}{|c|}{ per unit of capital } & \multicolumn{3}{|c|}{ in thousand USD } \\
\hline & & GDP/K & $\mathrm{I} / \mathrm{K}$ & $\mathrm{S} / \mathrm{K}$ & $\mathrm{Sd} / \mathrm{K}$ & $\mathrm{Pr} / \mathrm{K}$ & GDP/L & $\mathrm{Wr} / \mathrm{L}$ & $\mathrm{Wn} / \mathrm{L}$ \\
\hline \multirow[t]{2}{*}{ Slovenia } & 1997-99 & 0.266 & 0.067 & 0.067 & 0.064 & 0.061 & 25.971 & 19.829 & 25.656 \\
\hline & $2000-02$ & 0.276 & 0.068 & 0.068 & 0.067 & 0.065 & 28.370 & 21.669 & 34.339 \\
\hline \multirow{2}{*}{$\begin{array}{l}\text { Czech } \\
\text { Republic }\end{array}$} & 1997-99 & 0.213 & 0.061 & 0.061 & 0.053 & 0.105 & 11.632 & 5.913 & 7.229 \\
\hline & 2000-02 & 0.206 & 0.059 & 0.059 & 0.048 & 0.102 & 12.997 & 6.594 & 8.864 \\
\hline \multirow[t]{2}{*}{ Germany } & 1997-99 & 0.292 & 0.062 & 0.062 & 0.061 & 0.113 & 68.212 & 41.107 & 42.287 \\
\hline & $2000-02$ & 0.301 & 0.055 & 0.055 & 0.058 & 0.107 & 67.855 & 41.827 & 45.035 \\
\hline \multirow[t]{2}{*}{ Greece } & 1997-99 & 0.466 & 0.102 & 0.102 & 0.067 & 0.239 & 33.158 & 16.144 & 19.275 \\
\hline & $2000-02$ & 0.472 & 0.113 & 0.113 & 0.085 & 0.269 & 37.657 & 16.190 & 21.145 \\
\hline \multirow[t]{2}{*}{ Ireland } & 1997-99 & 0.419 & 0.097 & 0.097 & 0.102 & 0.199 & 57.500 & 30.198 & 34.016 \\
\hline & 2000-02 & 0.409 & 0.096 & 0.096 & 0.093 & 0.194 & 66.731 & 35.083 & 44.271 \\
\hline
\end{tabular}

Source: National Accounts Statistics, UN, 2003 and 2005; authors' calculations.

\section{Model}

The post-Keynesian long-run economic model of a market economy with private ownership is applied (Robinson and Eatwell, 1962; Tajnikar, 1996, 2000). A very important feature of post-Keynesian macrodynamics is its stress on accumulating and utilising productive resources rather than their scarcity and allocation. Therefore, the core economic aggregate in the model is investments which not only create both aggregate demand and new productive capacity (Harrod, 1939) but, through the growth of demand, also influence the size of the labour force and the pace of technological progress (Setterfield, 2001).

Investments are the result of the expectations of economic subjects (Harris, 1978). When the expectations are subject to fundamental uncertainty about the future, they are influenced by the growth of demand in the recent past and the extent to which short-run expectations have been realised or disappointed (Setterfield, 
1999). On the one hand, investments determine the necessary savings that are formed from incomes according to the propensities to save of different groups of economic subjects. By definition, in every economy investments must equal savings. When the savings of domestic economic subjects are insufficient, a deficit in the current account appears (Kalecki, 1954, p. 49). With domestic economic subjects' given propensity to save, investments determine both the domestic income and current account balance. A negative current account is therefore a consequence of an insufficient propensity to save, considering the given income distribution among economic subjects. According to the Pasinetti paradox, savings from profits are crucial for the value of domestic aggregate savings (Pasinetti, 1962, 1974). We thus have a relationship between accumulation and profits, where the causation runs from the latter to the former (Arestis, 1992, p. 212). If profits are expressed per unit of capital, we talk about the profit rate. The profit rate divides gross domestic product into profits and real wages. The latter are therefore a residual, after investments determine profits (Kalecki, 1954). The more efficient the economy, the higher real wages can be (per unit of labour) at a given profit rate.

Aggregate demand or, more concretely, discretionary expenditure in which investment plays an important role, is the moving force of aggregate output growth and employment (Arestis, 1992). Investments relative to existing capital represent the investment rate and determine the growth of gross domestic product. With an unaltered technical structure, the investment rate through output growth also determines the growth of employed labour.

Thus, with all other economic categories remaining unchanged the investment rate reflects the aggregate demand for labour. Together with the supply of labour, demand for labour in the labour market determines nominal wages. Although nominal and real wages are influenced by the investment rate, there is no reason for both wage categories (real and nominal) to be the same as they are also influenced by other factors. The discrepancy between - according to the investment rate - feasible real wages and nominal wages is suppressed by prices, which complete two circles of the economic influence of the investment rate. Money prices are therefore the result of a complex power struggle - between both capital and labour, and among capitalists (Wray, 2001).

\subsection{Graphical Presentation of the Model}

On the theoretical basis described above and taking into account the data from Table 2 , a graphical presentation of the model for each analysed country is constructed. In the figures we compare the national economy's macroeconomic situations in both analysed periods. Afterwards we analyse each of the four quadrants of the figures one by one. The first quadrant shows the relationship between investment, domestic savings and profit rates. The efficiency of capital, productivity of labour and real wages are presented in the second quadrant, the third shows the labour market situation while the fourth reveals price dynamics. 
Figure 1

Macroeconomic Development in Slovenia in 1997-1999 and 2000-2002

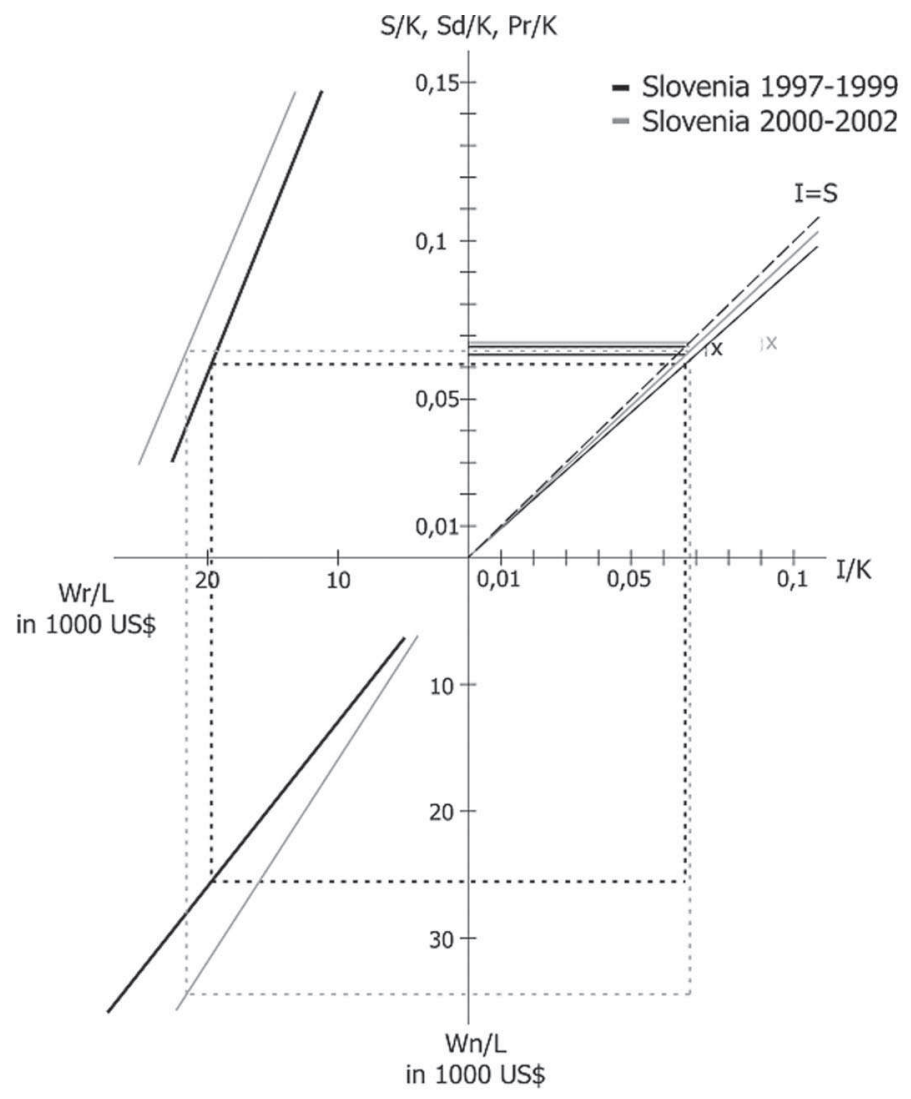

Source: National Accounts Statistics, UN, 2003 and 2005; authors' calculations. 
Figure 2

Macroeconomic Development in Czech Republic in 1997-1999 and 2000-2002

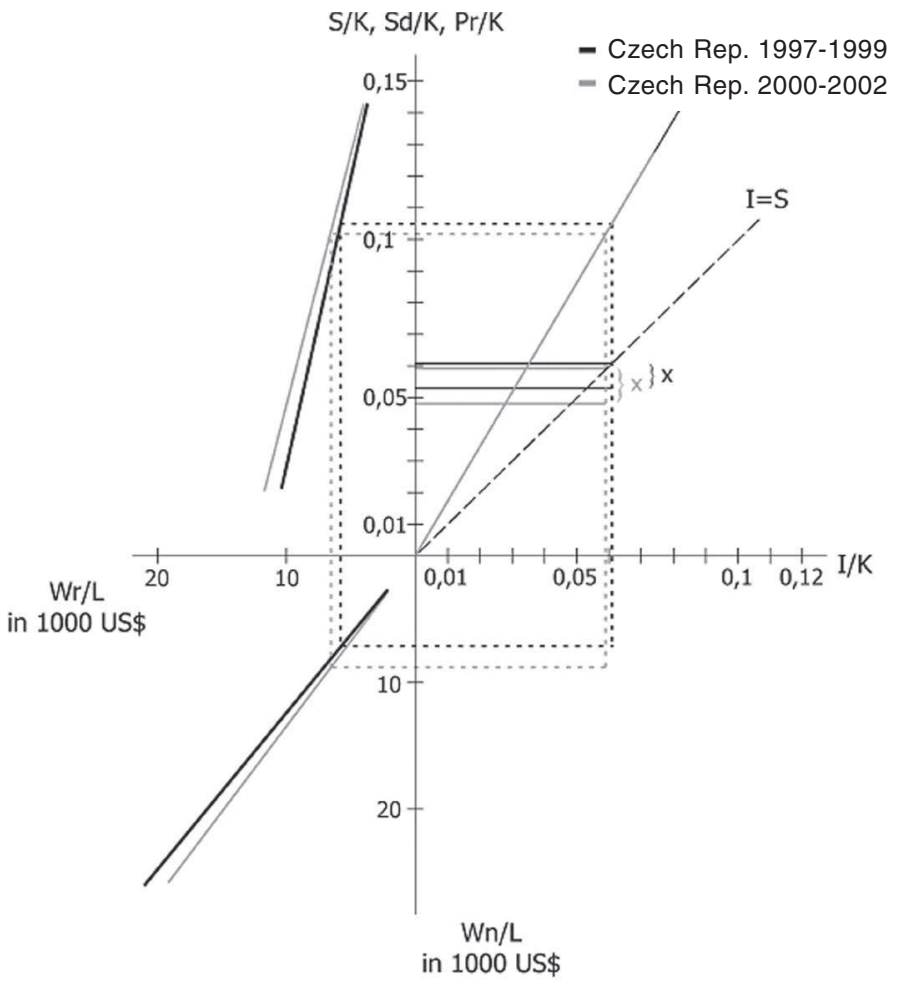

Source: National Accounts Statistics, UN, 2003 and 2005; authors' calculations. 
Figure 3

Macroeconomic Development in Germany in 1997-1999 and 2000-2002

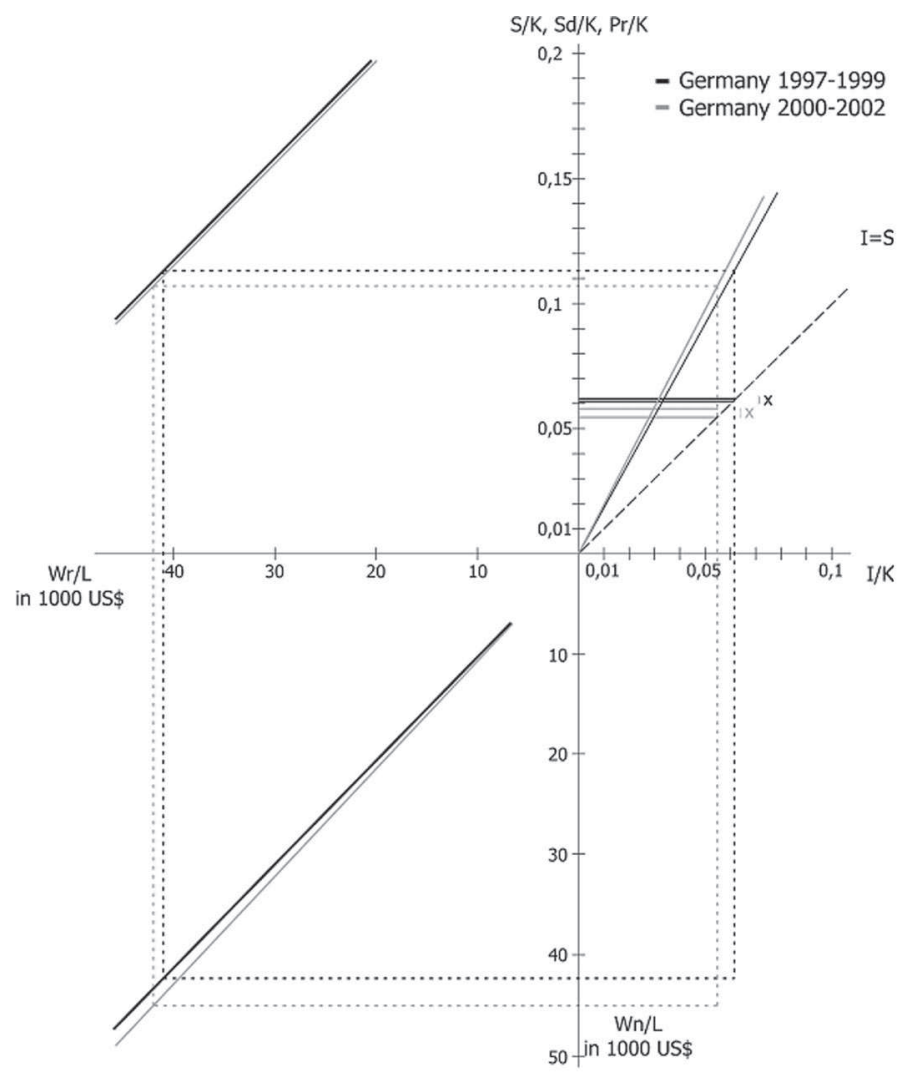

Source: National Accounts Statistics, UN, 2003 and 2005; authors' calculations. 
Figure 4

Macroeconomic Development in Greece in 1993-1996 and 1997- 2000

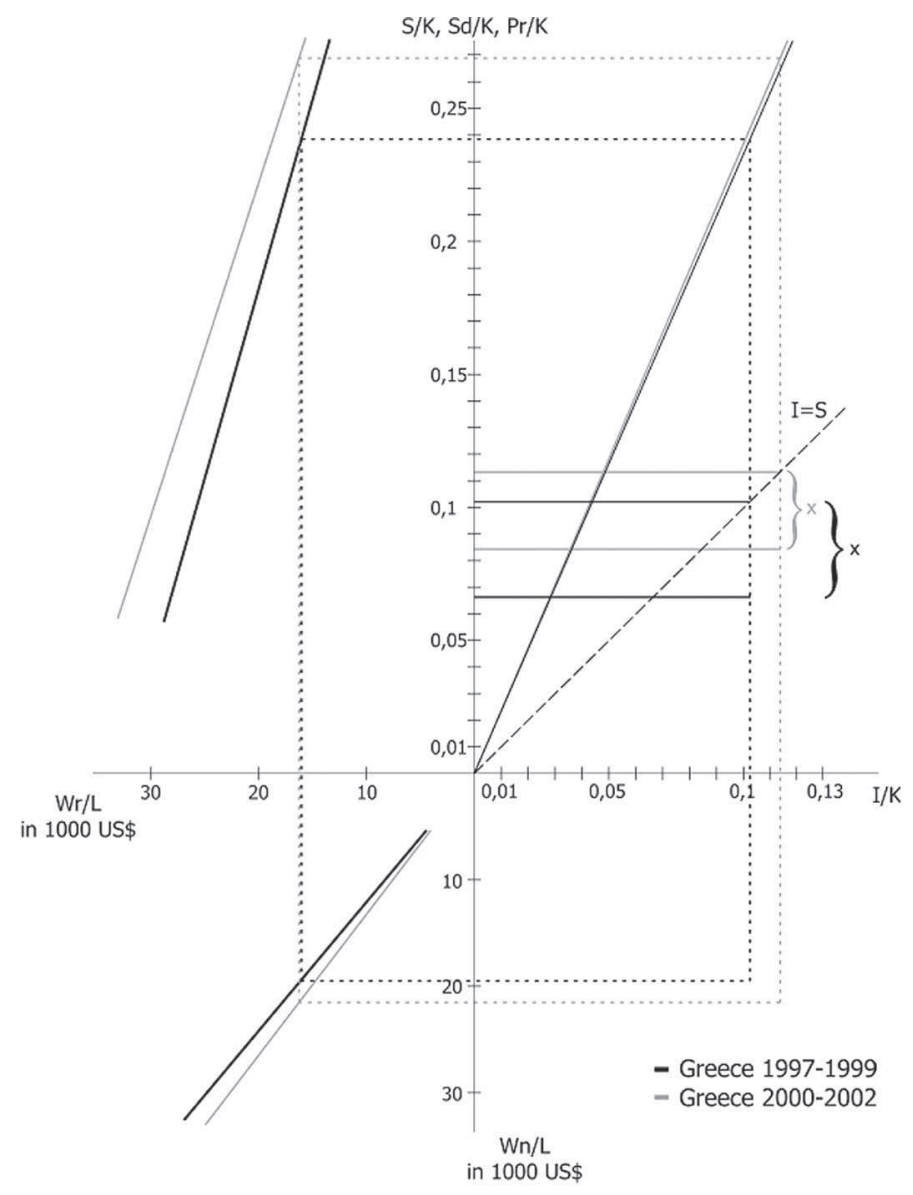

Source: National Accounts Statistics, UN, 2003 and 2005; authors' calculations. 
Figure 5

Macroeconomic Development in Ireland in 1997-1999 and 2000-2002

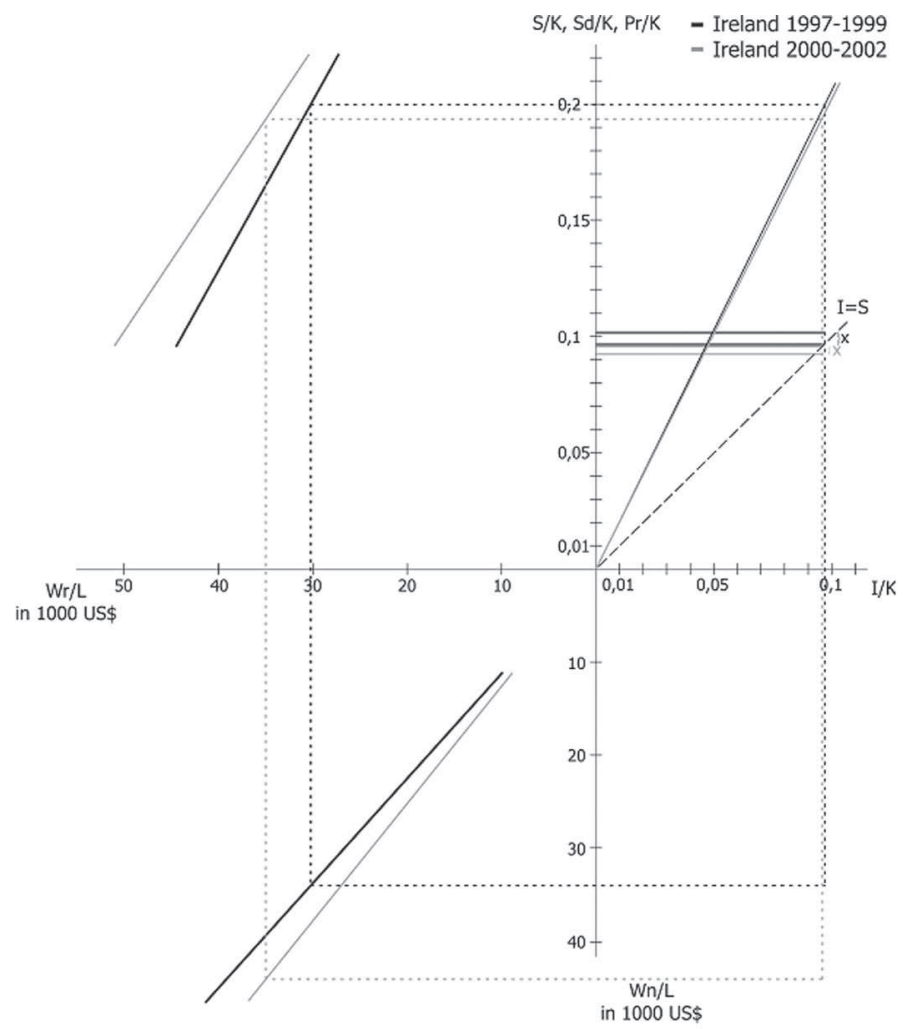

Source: National Accounts Statistics, UN, 2003 and 2005; authors' calculations. 


\subsection{Investments, Savings and Profits}

We can observe the investments, savings and growth of each analysed country in the first quadrant of Figures 1-5. Since investments allow production capacities to grow, the level of investment in a national economy is a very important issue. Empirical analyses show (e.g. Hussein, Thirlwall, 2000) that a large proportion of growth is explained by the rate of investing. On the other hand, the profit rate and profit share significantly explain investment spending and growth of the capital stock (Glyn, 1997, Seguino 1999-2000).

When investments are the outcome of economic expectations, investment pessimism can be seen in countries with low investment rates. According to an empirical study for Slovenia (Tajnikar, Ogrin, 2001), the large share of this pessimism is linked to the acceleration principle. A fall in gross domestic product growth affects investment activity. However, it can be empirically established that investment decisions in Slovenia are influenced by profit expectations. Unfortunately, the undefined and unsuitable ownership structure in Slovenia is only able to lead to weak profit motives. In these circumstances, economic subjects only invest when demand (short-term factor) leads to full capacity utilisation (Tajnikar, Ogrin, 2001).

From the ratios and figures presented above, we can in investment-rate terms rank countries from that with the highest investment rate $(\mathrm{I} / \mathrm{K})$ to that with the lowest in the 1997-1999 period in the following order: Greece, Ireland, Slovenia, Germany and the Czech Republic. In the second investigated period of 2000-2002 it was revealed a similar situation, with Germany and the Czech Republic swapping their places in the ranking. The investment rate was very similar and relatively low in the Czech Republic, Germany and Slovenia. Greece had the highest investment rate in both periods, closely followed by Ireland. Germany experienced a relatively high decrease in the investment rate between the two investigated periods, while in other countries there were no substantial changes in the height of the investment rate. Nevertheless, we have to acknowledge, that when ranking the countries according to their investment rates, a low investment rate measured by the ratio $\mathrm{I} / \mathrm{K}$ in a particular country, does not necessarily mean that investment expenditures are low. When a national economy holds a large amount of capital and invests substantially, the investment rate might still be relatively low. On the other hand, a national economy with a low capital level could have a high investment rate even when investing moderately.

By definition, investment equals saving in every economy. With the exception of Ireland in the 1997-1999 period and Germany in the 2000-2000 period, in all of the analysed countries domestic savings ( $\mathrm{Sd}$ ) were insufficient to cover investments (I) and a negative current account (X) appeared as a result. In Ireland the positive current account balance in the first period turned into negative in the second period due to smaller propensity to save from domestic income and thus decrease in domestic savings at almost unaltered investment rate. In Germany, where the propensity to save from domestic income even lessened between the analysed periods, the positive current account is mainly the consequence of more modest investment activity, reflecting in smaller investment rate.

At a given investment rate the current account deficit is lower when the propensity to save is higher. Of all analysed countries the propensity to save was highest 
in the Czech Republic (25.1\%) in the period 1997-1999. Table 3 reveals, how the current account balance would have been different, when analysed countries had faced higher propensity to save from domestic income. We present the current account balance (X) as a percentage of GDP if the propensity to save in all analysed countries were to be increased to the Czech Republic's level in the first period. It is obvious that the current account deficits could have been substantially reduced and/ or turned into surpluses if in most of these countries had the domestic propensities to save been higher.

Table 3

\section{Propensity to Save and Current Account Balances in the Investigated Periods}

\begin{tabular}{|l|c|c|c|c|c|c|c|c|c|c|}
\hline & \multicolumn{2}{|c|}{ Slovenia } & \multicolumn{2}{c|}{ Czech Rep. } & \multicolumn{2}{c|}{ Germany } & \multicolumn{2}{c|}{ Greece } & \multicolumn{2}{c|}{ Ireland } \\
\cline { 2 - 10 } & $\begin{array}{l}1997- \\
1999\end{array}$ & $\begin{array}{l}2000- \\
2002\end{array}$ & $\begin{array}{l}1997- \\
1999\end{array}$ & $\begin{array}{l}2000- \\
2002\end{array}$ & $\begin{array}{l}1997- \\
1999\end{array}$ & $\begin{array}{l}2000- \\
2002\end{array}$ & $\begin{array}{l}1997- \\
1999\end{array}$ & $\begin{array}{l}2000- \\
2002\end{array}$ & $\begin{array}{l}1997- \\
1999\end{array}$ & $\begin{array}{l}2000- \\
2002\end{array}$ \\
\hline $\begin{array}{l}\text { Propensity to save } \\
\text { from domestic } \\
\text { income }\end{array}$ & 0.240 & 0.243 & 0.251 & 0.230 & 0.215 & 0.206 & 0.143 & 0.181 & 0.244 & 0.227 \\
\hline $\begin{array}{l}\text { Current account } \\
\text { balance in US\$ } \\
\text { million }\end{array}$ & -286 & -93 & -2105 & -3492 & -9743 & 21264 & -9711 & -8031 & 1153 & -767 \\
\hline $\begin{array}{l}\text { Current account } \\
\text { balance as \% of GDP }\end{array}$ & -1.26 & -0.36 & -3.60 & -5.54 & -0.38 & 0.81 & -7.53 & -5.43 & 1.32 & -0.66 \\
\hline $\begin{array}{l}\text { Current account } \\
\text { balance at the level } \\
\text { of Czech propensity } \\
\text { to save in the period } \\
\begin{array}{l}\text { 1997-1999 in US\$ } \\
\text { million }\end{array}\end{array}$ & -47 & 95 & -2105 & -2213 & 82030 & 138987 & 4154 & 2257 & 1695 & 1972 \\
\hline $\begin{array}{l}\text { Current account } \\
\text { balance as \% of GDP } \\
\text { at the level of Czech } \\
\text { propensity to save }\end{array}$ & -0.21 & 0.37 & -3.60 & -3.51 & 3.20 & 5.28 & 3.22 & 1.53 & 1.94 & 1.70 \\
\hline
\end{tabular}

Source: National Accounts Statistics, UN, 2003 and 2005; authors' calculations.

At the same time, at a given investment rate and higher propensity to save the profit rate is lower. The relationship between the investment rate $(\mathrm{I} / \mathrm{K})$ and profit rate $(\mathrm{Pr} / \mathrm{K})$ shows the slope of a straight line in the first quadrant, which is the graphical presentation of the Cambridge equation. If we look at profit rates, the ranking of countries from highest to lowest differs from the country rankings based on investment rates, as shown in Table 4, and the different slopes of the Cambridge equation's straight lines for each country.

In the 1997-1999 period the country ranks according to the investment rate meets ranking with regard to the profit rate only in the case of Greece and Ireland, while the investment and profit rate ranks of the Czech Republic, Germany and Slovenia 
do not correspond. Relative high propensity to save from domestic income and a deficit in current account allowed Slovenia to finance a higher investment rate at a lower profit rate than Germany and the Czech Republic. Greece was evidently able to finance its high investment rate through and high profit rate a high current account deficit. The Irish investment could have been higher at a given propensity to save and at a given profit rate when the deficit in the current account occurred.

In the 2000-2002 period rankings of the countries were very similar. Greece and Ireland were still in first and second places according to investment and the profit rate. Greek investment rate increased in the second period with regard to the first period (1.1 p.p.) but less that its profit rate ( 3 p.p.). The latter is the consequence of the lower current account deficit which an even higher propensity to save could not compensate. At almost unaltered investment and profit rate, when compared to the first period, Ireland partially substituted domestic foreign savings in investment financing, which is evident from a decrease in the propensity to save from domestic income and a higher deficit in current account. In Germany investment rate decreased at a greater extent than the profit rate as a result of a lower propensity to save from domestic income and a positive current account in the second period. Czech investment and profit rate decreased almost proportionately. However, a lower propensity to save from domestic income in the Czech Republic at almost unaltered investment and profit rate resulted in a higher deficit in the current account. In Slovenia profit rate increased more than the investment rate mainly due to a lower current account deficit.

Table 4

Rankings of the Analysed Countries according to Investment and Profit Rates in the Investigated Periods

\begin{tabular}{|l|c|c|l|c|c|}
\hline \multicolumn{3}{|c|}{$1997-1999$} & \multicolumn{3}{c|}{ 2000-2002 } \\
\hline Rank & $\begin{array}{c}\text { According to invest- } \\
\text { ment rate (I/K) } \\
\text { Descending }\end{array}$ & $\begin{array}{c}\text { According to profit } \\
\text { rate (Pr/K) } \\
\text { Descending }\end{array}$ & Rank & $\begin{array}{c}\text { According to invest- } \\
\text { ment rate (I/K) } \\
\text { Descending }\end{array}$ & $\begin{array}{c}\text { According to profit } \\
\text { rate (Pr/K) } \\
\text { Descending }\end{array}$ \\
\hline 1 & Greece & Greece & 1 & Greece & Greece \\
\hline 2 & Ireland & Ireland & 2 & Ireland & Ireland \\
\hline 3 & Slovenia & Germany & 3 & Slovenia & Germany \\
\hline 4 & Germany & Czech Republic & 4 & Czech Republic & Czech Republic \\
\hline 5 & Czech Republic & Slovenia & 5 & Germany & Slovenia \\
\hline
\end{tabular}

Source: National Accounts Statistics, UN, 2003 and 2005; authors' calculations.

This shows how important the saving behaviour of domestic economic agents really is, along with the importance of savings from capital incomes. A higher propensity to save from domestic income at a given investment rate leads to lower profit rates and the lower external indebtedness of national economies. 


\subsection{Efficiency and Real Households and State Incomes}

The second quadrant of the figures shows changes in economic efficiency and changes in the real incomes of households and the state. The straight line Wr-Pr reveals the economy's efficiency. We can observe the economic efficiency of the analysed countries in both absolute terms and from the relative factor efficiency aspect.

The straight lines $\mathrm{Wr}-\mathrm{Pr}$ in the second quadrant of the figures reveal the levels of real incomes of households and the state per employee that can be earned at a given profit rate. The greater the absolute efficiency of the economy, the higher real wages can be at a given profit rate. Economic efficiency depends on both the utilisation of capital and labour. The economy is more efficient the more the straight line $\mathrm{Wr}-\mathrm{Pr}$ is on the left side of the second quadrant of the figure.

We can see that the efficiency lines of Germany and Ireland are most distant from the origin in the 1993-1996 period as well as in 1997-2000, which shows the highest economic efficiency of these two countries at that time. Greece followed closely behind. Closest to the origin lies the straight line Wr-Pr of the Czech Republic. Efficiency in Slovenia is higher than in the Czech Republic, although it still lags far behind compared to the most efficient countries Germany and Ireland. In the second period the situation remained almost the same. However, we also have to consider relative factor efficiency before any conclusions.

Relative factor efficiency is revealed by the slope of the straight line Wr-Pr. It depends on the intersection of the straight line $\mathrm{Wr}-\mathrm{Pr}$ with the ordinate and abscissa axes. The intersection of $\mathrm{Wr}-\mathrm{Pr}$ with the ordinate shows the ratio GDP/K or, in other terms, the highest profit rate possible in the economy. On the other hand, the intersection of the straight line Wr-Pr with the abscissa axis shows the maximum level of real wages per employee when the profit rate is zero. The steeper the straight line, the more efficient capital is relative to labour. The flatter the slope of the straight line, the more productive labour is relative to capital efficiency.

In Table 5 we present the slopes of the straight lines Wr-Pr of the analysed countries in both periods of investigation. The slope of the straight line Wr-Pr represents relative factor efficiency and is calculated as the ratio of the highest possible profit rate $(\mathrm{GDP} / \mathrm{K})$ and the maximum level of real wages per employee (GDP/L). It has to be emphasised that relative factor efficiency only expresses the ratio between the efficiency of capital and labour productivity and does not show the absolute efficiency level of the production factors. It is obvious that we were witnessing the lowest capital efficiency (measured by GDP/K) relative to labour productivity (GDP/L) in Germany and the highest in the Czech Republic in both periods. Of course, the ran-

Table 5

Relative Factor Efficiency in 1997-1999 and 2000-2002

\begin{tabular}{|l|c|c|c|c|c|}
\hline $\begin{array}{l}\text { Relative factor } \\
\text { efficiency in } 10^{3}\end{array}$ & Slovenia & Czech Rep. & Germany & Greece & Ireland \\
\hline $1997-1999$ & -0.0103 & -0.0183 & -0.0043 & -0.0141 & -0.0073 \\
\hline $2000-2002$ & -0.0097 & -0.0159 & -0.0044 & -0.0125 & -0.0061 \\
\hline
\end{tabular}

Source: National Accounts Statistics, UN, 2003 and 2005; authors' calculations. 
king of the countries would be the opposite if we measured labour productivity relative to capital efficiency.

When observed alone (Table 2), the labour productivity (GDP/L) was the highest in Germany, followed by Ireland and Greece, while the lowest level was found in the Czech Republic during 1997-2002. All of the analysed countries experienced the growth of labour productivity during the two analysed periods. The ratio between the lowest labour productivity (the Czech Republic) among the analysed countries and the highest (Germany) is $1: 5.9$ in the first and $1: 5.2$ in the second period. This ratio reflects the huge gap in labour productivity in the analysed countries. However, over time the differences in labour productivity are slowly becoming smaller. According to Table 2, there are also quite large differences in capital efficiency $(\mathrm{GDP} / \mathrm{K})$ among the analysed countries. However, they are much smaller than those in labour productivity. The ratio between the lowest capital efficiency among the analysed countries (the Czech Republic) and the highest (Greece) is approximately $1: 2.2$ in the period 1997-1999 and $1: 2.3$ in the period 2000-2002. We can see that the trend of the differences in the capital efficiency is quite the opposite to the trend of the labour productivity. The increase in the gap in the capital efficiency should be of great concern.

In Table 6 the countries are ranked according to their profit rates and real wages per employee. At a given economic efficiency countries with the highest profit rates should experience the lowest level of real wages per employee. However, while having the lowest profit rate (rank 5) Slovenia did not have the highest real wages per employee. The first place (rank 5) in ranking according to the actual real wage per employee belonged to Germany, followed by Ireland. Although these two countries had relatively high profit rates, high real wages were feasible due to the high absolute efficiency of the economy (the straight lines Wr-Pr lie far above the origin in the second quadrant). During the two analysed periods there were no changes in the countries' ranks.

Table 6

Rank of the Analysed Countries according to Profit Rate and Real Wages per Employee in Investigated Periods

\begin{tabular}{|l|c|c|l|c|c|}
\hline \multicolumn{3}{|c|}{$1997-1999$} & \multicolumn{3}{c|}{$2000-2002$} \\
\hline Rank & $\begin{array}{c}\text { According to profit } \\
\text { rate (Pr/K) } \\
\text { Descending }\end{array}$ & $\begin{array}{c}\text { According to real } \\
\text { wages per employee } \\
\text { (Wr/L) Ascending }\end{array}$ & Rank & $\begin{array}{c}\text { According to profit } \\
\text { rate (Pr/K) } \\
\text { Descending }\end{array}$ & $\begin{array}{c}\text { According to real } \\
\text { wages per employee } \\
\text { (Wr/L) Ascending }\end{array}$ \\
\hline 1 & Greece & Czech Republic & 1 & Greece & Czech Republic \\
\hline 2 & Ireland & Greece & 2 & Ireland & Greece \\
\hline 3 & Germany & Slovenia & 3 & Germany & Slovenia \\
\hline 4 & Czech Republic & Ireland & 4 & Czech Republic & Ireland \\
\hline 5 & Slovenia & Germany & 5 & Slovenia & Germany \\
\hline
\end{tabular}

Source: National Accounts Statistics, UN, 2003 and 2005; authors' calculations. 
It is quite obvious from Table 6 that higher profit rates do not always result in lower real wages per employee due to large differences in the absolute efficiency of the analysed countries. If all of the countries had the efficiency straight line of Germany then the real wages of their workers could be much higher at their given profit rates. This shows the importance of the position and slope of the straight line Wr-Pr. In other words, the absolute efficiency of an economy and the relative efficiency of factors of production are crucial from the factor income level viewpoint.

\subsection{Labour Market, Employment and Money Wages}

The investment rate influences the growth of production capacities. When the relationship between capital and labour is unaltered, investments must lead to the greater employment of labour. Therefore, a higher investment rate should also increase the rate of employment. In other words, there is a positive relationship between employment and autonomous expenditures, especially investment (Atesoglu, 2000). Higher employment leads to greater labour demand. With a given level of labour supply, this should affect the nominal price of labour.

We can observe the demand for labour (investment rate) and nominal wages in the fourth quadrant of the figures. As there were no substantial changes in the rankings of the analysed countries according to investment rates and nominal wages levels during the periods, we can draw similar conclusions for the whole period 1997-2002. It is obvious that in a cross-country comparison we cannot find the theoretical linkage of a higher investment rate leading to higher nominal wages per employee. Greece with the highest investment rate had one of the lowest nominal wages per employee among the analysed countries. On the other hand in Germany, where the investment rate is one of the lowest, the nominal wages per worker are the highest. The theoretical foundation that a higher investment rate leads to larger demand for labour and therefore to higher nominal wages per employee does not hold in the cross-country analysis. Only when the price levels were equal among the analysed countries a higher investment rate would lead to higher nominal wages. When the price levels are not the same across countries, price level growth is not only the consequence of the real-to-nominal wage relationship.

When we observe each of the analysed countries separately we can find the theoretical relationship of a higher investment rate leading to higher nominal wages only in Slovenia and Greece. But even for the Slovenian labour market in the second half of the 1990s the research shows (Tajnikar, 2000) that the excess supply of labour was not large enough to put a cap on nominal wage growth. This points out the inability of the labour market to function properly and that nominal wages were often defined regardless of labour market circumstances. This was clearly the case of Slovenia during the period of investigation, when the problem remained of incomes that were not determined in the market (e.g. the state administration's employees, pensioners, and public service employees). Wages in the business sector were in the investigated period still too closely tied to the incomes of firms by virtue of the high share of internal ownership seen in the business sector. The labour market was evidently highly imperfect as it required a high level of unemployment to stabilise nominal wages in the economy. A more detailed analysis for other 
analysed countries might show similar or other reasons for the absence of the theoretical relations of the observed variables in practice.

\subsection{Prices}

In the third quadrant of the model the slope of the straight line represents prices or, more precisely, the GDP deflator. The steeper the straight line, the higher is the level of prices in the economy. The difference in dynamics - according to the investment rate - of feasible real wages and nominal wages is suppressed by prices. In this way, the two-way influence of the investment rate is completed by prices. With everything else being given, higher investments lead to higher price level growth (McClain, Nichols, 1993-94). Empirical investigations (Atesoglu, 2000, 1997) also support the positive (one-to-one) cointegration between inflation and the rate of growth in unit labour costs with the cointegration coefficient of the wage cost-markup equation close to one. These results demonstrate the reliability of the wage-cost markup model of inflation.

In our analysis, all of the observed aggregates are in fixed UD\$ prices from 1995. Therefore, all the straight lines in the price quadrant would have a 45-degree slope in 1995. Any deviation of the price straight line from the 45-degree slope in the analysed periods is therefore an outcome of dissimilarities in nominal and real wage dynamics. The steeper the price straight line, the higher the ratio between nominal and real wages and thus higher price level growth. In Table 7 we present the ratios between nominal and real wages per employee for the analysed countries.

Table 7

Ratios between Nominal and Real Wages per Employee in 1997-1999 and 2000-2002

\begin{tabular}{|l|c|c|c|c|c|}
\hline $\mathrm{Wn} / \mathrm{Wr}$ & Slovenia & Czech Rep. & Germany & Greece & Ireland \\
\hline $1997-1999$ & 1.295 & 1.223 & 1.029 & 1.194 & 1.126 \\
\hline $2000-2002$ & 1.585 & 1.344 & 1.077 & 1.306 & 1.262 \\
\hline
\end{tabular}

Source: National Accounts Statistics, UN, 2003 and 2005; authors' calculations.

Because real wages are expressed in fixed US\$ 1995 prices and none of the analysed countries experienced deflation in any of the periods, the relationship between the nominal and real wage is more than 1 in both analysed periods and higher in the second period. However, the ratios between the levels of average nominal and real wages in the period do differ a great deal between countries. In Slovenia, the average nominal wage in the second period was $58.5 \%$ higher than average real wage, while in Germany the ratio equals only 1:1.077. This is graphically presented by the steepest price straight line in the price quadrant for Slovenia and the flattest price straight line of Germany. From the ratios, presented in the Table 7, we can also conclude that there must have been substantial differences in average annual price level growth among the analysed countries, with the lowest in Germany and the highest in Slovenia.

In Table 8 we rank the countries according to the level of their real and nominal wages per employee. It is obvious that a higher real wage is strongly correlated to a 
higher nominal wage. The outcome of both periods investigated is identical. There are no exceptions from the theoretical linkage even though there were quite large discrepancies in price level growth in the analysed countries. When we analyse inflationary factors and their impact on price levels, labour productivity and capital efficiency clearly have an important influence on the inflation level.

Table 8 Rankings of the Analysed Countries according to Real and Nominal Wages per
Employee in Investigated Periods

\begin{tabular}{|l|c|c|l|c|c|}
\hline \multicolumn{3}{|c|}{$1997-1999$} & \multicolumn{3}{c|}{$2000-2002$} \\
\hline Rank & $\begin{array}{c}\text { According to real } \\
\text { wages per employee } \\
\text { (Wr/L) Ascending }\end{array}$ & $\begin{array}{c}\text { According to nominal } \\
\text { wages per employee } \\
\text { (Wn/L) Ascending }\end{array}$ & Rank & $\begin{array}{c}\text { According to real } \\
\text { wages per employee } \\
\text { (Wr/L) Ascending }\end{array}$ & $\begin{array}{c}\text { According to nominal } \\
\text { wages per employee } \\
\text { (Wn/L) Ascending }\end{array}$ \\
\hline 1 & Czech Republic & Czech Republic & 1 & Czech Republic & Czech Republic \\
\hline 2 & Greece & Greece & 2 & Greece & Greece \\
\hline 3 & Slovenia & Slovenia & 3 & Slovenia & Slovenia \\
\hline 4 & Ireland & Ireland & 4 & Ireland & Ireland \\
\hline 5 & Germany & Germany & 5 & Germany & Germany \\
\hline
\end{tabular}

Source: National Accounts Statistics, UN, 2003 and 2005; authors' calculations.

In the whole 1997-2002 period Slovenia had a low growth rate, a high propensity to save and relatively satisfactory efficiency in the group of analysed countries. Such macroeconomic conditions should lead to a relatively low inflation rate. Yet inflation was relatively high. In our model high inflation can only originate from the labour market, where the level of nominal wages is formed. We could say that in Slovenia the dynamics of all the present macroeconomic factors should lead to low inflation (with the exception of the current account, which had a surplus). The high inflation was therefore obviously the consequence of the way nominal wages were determined in the labour market.

In Greece the majority of its macroeconomic characteristics in the 1997-2002 period indicate a high inflation level. However, the inflation rate was not one of the highest among the analysed countries due to the high level of efficiency of the Greek economy. As a result, its high economic efficiency, high economic growth and low propensity to save did not lead to high growth in price levels. The situation was quite similar in Ireland. Its high investment rate, very high profit rate and the positive or almost balanced current account were compensated for by high economic efficiency and ultimately resulted in a low inflation rate. In Germany the moderate investment rate, almost balanced current account and especially the very high economic efficiency resulted in a small increase in price levels.

The Czech economy had a modest growth rate together with the lowest economic efficiency among the investigated countries. Its high propensity to save from domestic income and obviously the stable conditions in the labour market, where 
nominal wages are determined, prevented the price level to increase even faster in the 1997-2002 period.

\section{Sources of Differences between Slovenia and Other Countries and Recommendations for Economic Policy}

Macroeconomic efficiency and stability are usually measured by employment, price-level stability and real income growth. Our model does not allow us to address employment issues but it does enable us to investigate economic efficiency, the current account balance, levels of real and nominal wages and price stability in national economies.

From the figures, as interpreted above, it is evident that there are several important differences in the macroeconomic situations of the countries analysed. If we take Slovenia as a reference country, the Czech Republic and Germany have lower and Ireland and Greece have higher investment rates in both analysed periods. Since investments increase production capacities, low investment rates could provide a warning sign of investment pessimism and a potential recession. Improving the investment expectations and raising the investment level are therefore areas on which economic policy should focus with its investment policy.

With the exception of the Czech Republic and Ireland in the first period, the analysed countries have a lower propensity to save from domestic income than Slovenia. In countries with the lowest propensity to save (Greece,) this leads to relatively high current account deficits. Current account deficits appear as a supplement to domestic savings for financing domestic investments. Although the Slovenian propensity to save grew between the periods, the increase in domestic savings was insufficient to cover the increase in investments and the investment rate. As a result, the current account was still in deficit in the second period, although the deficit decreased. A higher propensity to save from domestic savings could therefore at least partly resolve negative current account issues. Foreign capital inflows are another important option because they do not add to the external indebtedness of a country. At a given investment rate the profit rate can be lower and real wages thus higher, together with a lower current account deficit when the propensity to save from domestic incomes is higher. Evidently, the macroeconomic policy must focus on the propensity to make domestic savings. Boosting the propensity to save is the only solution for stabilising foreign debt. At the same time, it is crucial for raising the real incomes of households and the state, and for price stability (e.g. SchmidtHebbel and Serven, 1999).

It is also very clear that there are no particular advantages of nominal wage growth. In the short run, some structural changes among different income classes are possible although they are limited in the long run. In the longer term, nominal wage growth only causes inflation. In the investigated period Slovenia experienced the highest increase in price levels. At the same time, Slovenia had a lower investment rate that Greece and Ireland. The latter should be reflected in lower inflation as regard to Greece and Ireland through lower economic growth, via lower labour demand and lower nominal wages. However, this was not the case of Slovenia where the excess labour supply could not stabilise the nominal wage growth. Incomes policy has to be complemented with labour market policy in order to achieve grea- 
ter nominal wage stability and lower unemployment rates in countries like Slovenia. This is especially important as studies (e.g. Atesoglu, 1996) indicate the significance of low inflation rates for maintaining high rates of economic growth.

Raising the efficiency of some of the analysed economies is also crucial for achieving higher real incomes and price stability. Although the comparison between the two periods shows that all countries experienced at least some improvements in economic efficiency (least of all in the Czech Republic), there are still vast discrepancies among them. An increase in economic efficiency - graphically a shift of the Wr-Pr efficiency line away from the origin - allows real incomes to grow and eases pressure on price levels. In both of the analysed periods Germany and Ireland were the countries with the highest economic efficiency. The structure of investments is of great importance for improving the efficiency of national economies. Economic policy should take measures to promote technical progress that boosts the effectiveness of employing capital (Kitson and Michie, 2000). On the other hand, the introduction of economic measures to raise labour productivity is particularly urgent in the Czech Republic.

Based on analysis presented above, we can therefore conclude that in more or less all of the analysed countries there should be a greater emphasis on tax policy to create incentives to invest and save, on incomes policy to control the dynamics of the nominal wage-price relation to avoid cost inflation, as well as on investment policy and technological policy as prerequisites for enhanced economic efficiency.

\section{References}

Arestis, P. The Post-Keynesian Approach to Economics. Aldershot: Edward Elgar, 1992.

Atesoglu, H.S. "A Demand-Oriented Explanation of Economic Growth in Germany." Journal of Post-Keynesian Economics, 1996, 19(1), pp. 101-111.

"A Post-Keynesian Explanation of United States Inflation." Journal of Post Keynesian Economics, 1997, 19(4), pp. 639-649.

"Income, Employment, Inflation and Money in the United States." Journal of Post Keynesian Economics, 2000, 22(4), pp. 639-646.

Carvalho, F.J. C. Mr Keynes and the Post Keynesians. Aldershot: Edward Elgar, 1992.

Garegnani, P. "Heterogeneous Capital, the Production Function and the Theory of Distribution." Review of Economic Studies, 1970.

Harris, D. J. Capital Accumulation and Income Distribution. Palo Alto: Stanford University Press, 1978.

Harrod, R.F. "An Essay in Dynamics Theory." Economic Journal, 1939, 49, pp. 14-33.

Hussein, K. and Thirlwall, A.P. "The AK Model of "New" Growth Theory in the Harrod-Domar Growth Equation: Investment and Growth Revisited." Journal of Post Keynesian Economics, 2000, 22 (3), pp. 427-436.

Kalecki, M. Theory of Economic Dynamics; An Essay on Cyclical and Long-Run Changes in Capitalist Economy. London: Unwin Brothers, 1954.

Kitson, M. and Michie, J. The Political Economy of Competitiveness. London and New York: Routledge, 2000.

McClain, K.T. and Nichols, L.M. "On the Relation between Investment and Inflation: Some Results from Cointegration, Causation, and Sign Tests." Journal of Post Keynesian Economics, 1993-94 16(2), pp. 205-220. 
Pasinetti, L. L. "Rate of Profit and Income Distribution in Relation to the Rate of Economic Growth." Review of Economic Studies, 1962, pp. 267-279.

Growth and Income Distribution, Essays in Economic Theory. Cambridge: Cambridge University Press, 1974.

Robinson, J. Essays in the Theory of Economic Growth. New York: St Martin's Press, 1962.

Robinson, J., Eatwell, J. An Introduction to Modern Economics. London: McGraw-Hill, 1973.

Schmidt-Hebbel, K., Serven, L. The Economics of Saving and Growth. Cambridge: Cambridge University Press, 1999.

Seguino, S. "The Investment Function Revisited: Disciplining Capital in South Korea." Journal of Post-Keynesian Economics, 1999-2000, 22 (2), pp. 313-338.

Setterfield, M.A. "Expectations, Path Dependence and Effective Demand: A Macroeconomic Model Along Keynesian Lines." Journal of Post-Keynesian Economics, 1999, 21(3), pp. 479501.

"Macrodynamics." in Holt, R. and Pressman, S. (eds.). A New Guide to PostKeynesian Economics. London and New York: Routledge, 2001, pp. 92-101.

Statistical Office of the Republic of Slovenia. A New Millennium - New Phenomena: Have Statisticians Been Able to Understand and Measure Them? Ljubljana: Statistical Office of the Republic of Slovenia, 2001.

Statistical Office of the Republic of Slovenia. Rapid Reports, No. 308, National Accounts. Ljubljana: Statistical Office of the Republic of Slovenia, 2003.

Statistical Office of the Republic of Slovenia. Rapid Reports, No. 262, National Accounts. Ljubljana: Statistical Office of the Republic of Slovenia, 2005.

Tajnikar, M. and Ogrin, N. "Post-Keynesian Explanation of the Transitional Adaptation of the Investment Function in Slovenia" in Fourth International Conference on "Enterprise in Transition' Proceedings. Split: Faculty of Economics Split, 2001.

Tajnikar M. "From a Labour-Managed Economy to a Market Economy: A Contribution to Economic Transformation." Atlantic Economic Journal, 2000, 28(1), pp. 93-103.

United Nations, Department of Economic and Social Affairs, Statistics Division. National Accounts Statistics: Main Aggregates and Detailed Tables, 2002-2003. New York: United Nations, 2005.

United Nations, Department of Economic and Social Affairs, Statistics Division. National Accounts Statistics: Main Aggregates and Detailed Tables, 2001. New York: United Nations, 2003.

Wray, L.R. "Money and Inflation." in Holt, R. and Pressman, S. (eds.) A New Guide to PostKeynesian Economics. London and New York: Routledge, 2001, pp. 79-91. 